\title{
SUPPLIER SELECTION IN PROCUREMENT LOGISTICS USING AHP-QFD AND ANP-QFD APPROACH
}

\author{
Vukašin Pajić ${ }^{1}$, Snežana Tadić ${ }^{2}$, Milorad Kilibarda ${ }^{3}$ \\ ${ }_{1,2,3}$ University of Belgrade, Faculty of Transport and Traffic Engineering, Vojvode Stepe 305, \\ 11000 Belgrade, Serbia
}

Received 6 January 2021; accepted 15 April 2021

\begin{abstract}
Procurement logistics stands out as one of the basic sectors in a logistics company. The other sectors in a company depend on procurement as it can cause downtime and delays that affect the entire company. In addition to the impact on the company itself, procurement can also have an impact on end-users, given that efficient procurement is one of the factors of competitiveness. One of the basic tasks of procurement logistics is the selection of suppliers. For this reason, the aim of this paper was to propose approaches based on AHP-QFD and ANP-QFD methodology in order to select suppliers. On that occasion, the evaluation of three suppliers was performed by applying eight criteria (price, product quality, on-time delivery, location, communication, reliability, flexibility, and reputation). The results of the application of the described methodologies also showed a different ranking of suppliers depending on the chosen methodology.
\end{abstract}

Keywords: procurement logistics, supplier selection, AHP, ANP, QFD.

\section{Introduction}

Supplier selection directly affects the efficiency of all processes in the field of procurement, production, distribution, and delivery of products. In addition, the supplier selection has an impact on the efficiency of the entire supply chain, given that cooperation with adequate suppliers can result in reduced costs but also reduced time required for delivery of raw materials (products). The importance of managing the procurement process is shown by the fact that procurement costs can be up to $70 \%$ of the costs of the final product (Bottani et al., 2018). Also, in industrial companies, the share of procurement in the total turnover ranges from 50-90\% (Taghizadeh and Ershadi, 2013). Based on this, it can be concluded that significant procurement can achieve significant savings and can affect the company's profitability. For this reason, the issue of supplier selection has been recognized both in the literature and in practice, where more and more attention is being paid to this process.

As the issue of choosing an adequate supplier is very complex, multi-criteria decisionmaking (MCDM) methods are often being used in the literature to solve this problem. Another reason for the implementation of these methods is that when choosing a supplier, it is necessary to consider several criteria at the same time. Given that the issue of supplier selection is so complex, one of

\footnotetext{
${ }^{1}$ Corresponding author: v.pajic@sf.bg.ac.rs
} 
the most commonly MCDM methods used on this occasion is the Analytic Hierarchy Process (AHP). The reason for this is the fact that when applying this method, the problem can be broken down into a hierarchical structure. In addition to AHP, the Analytic Network Process (ANP) method is often used, which is an upgrade to AHP, since it also observes the interrelationships between elements at different hierarchical levels, while AHP observes only the interrelationships between elements in relation to a hierarchically higher level. Precisely for these reasons, a methodology based on the mentioned methods together with the quality function deployment (QFD) method was applied in this paper. The QFD method was used in this paper to obtain the weights of the criteria which were then used to obtain the final supplier rank. In addition to AHP and ANP, TOPSIS, DEA, ELECTRE, and other methods are used to select suppliers.

The paper is organized as follows. In addition to the introduction, the second chapter describes the problem and provides a review of the literature on the application of the methods used in this paper. The third chapter describes the methodology of the paper, while the fourth chapter presents the results of the research and the application of the described methodology. Also, within this chapter, the criteria used for evaluating suppliers in this paper are defined. Finally, concluding remarks are given as well as directions for future research.

\section{Problem Description and Literature Review}

Interruption of the production process or unsatisfied demand can have major consequences for the company's profitability.
For this reason, it is necessary to choose a supplier who can support the existing demand but also who can provide the necessary flexibility in the event of sudden changes in demand. Non-compliance with the delivery deadline by the supplier directly affects the delay in delivery and the dissatisfaction of end-users. In practice, the process of procurement and selection of suppliers is often done through tenders. However, in order for companies to differentiate between different suppliers, it is necessary to use certain tools. In addition to business indicators (such as financial stability, business in previous years, experience, etc.), it is possible to apply some of the MCDM methods. The aim of this paper is to propose a methodology based on AHP-QFD and ANP-QFD approaches that can be used and assist in the supplier selection process.

A review of the literature revealed that there are numerous approaches (techniques) that can be used alone or in combination with others in order to select suppliers such as AHP, ANP, QFD and other MCDM methods in classic and fuzzy form. Although the application of MCDM methods independently in order to select suppliers is more popular in the literature, there are a large number of papers that have implemented a combination of methods. The reason for his lies in the fact that the use of a combination of methods allows the consideration of multiple aspects that can be considered simultaneously when evaluating alternatives (in this case suppliers), including quantitative and qualitative factors. The application of a combination of methods also enables the selection of the optimal supplier in terms of various aspects such as cost, quality, delivery, flexibility, reliability, etc. (Bottani et al., 2018). Bevilacqua et al. (2006) 
presented the first example of the application of the QFD method for supplier selection. In their approach, they first identified the characteristics that the product should have (WHATs) to meet the company's needs and then determined the supplier evaluation criteria (HOWs) in order to perform the final supplier ranking. A review of the literature showed that the QFD method is often combined with MCDM methods. The application of the QFD method with AHP and ANP methods is particularly suitable for decision-makers (Rajesh and Malliga, 2013). Bhattacharya et al. (2010) applied the fuzzy QFD methodology for supplier selection in their paper, combining it with the AHP method to determine the cost of the supplier selection process using a specific cost factor measure (CFM). In the papers (Rajesh and Malliga, 2013; Dai and Blackhurst, 2012) the AHP-QFD methodology for supplier selection was applied. Ho et al. (2011) developed a threephase AHP-QFD approach to increase decision-making efficiency. The goal of this approach was to identify stakeholders and then identify the best suppliers. Scott et al. (2015) developed an AHP-QFD approach for supplier selection and order allocation. An integrated approach based on AHP and QFD methods was developed by Dai and Blackhurst (2012), which consists of four steps (phases), connecting customer requirements with the company's strategy, determining sustainable purchasing competitive priority, determining sustainable selection criteria and ranking suppliers. Polat et al. (2017) presented an integrated fuzzy approach for supplier selection combining fuzzy AHP and fuzzy TOPSIS methods. In the presented methodology, the fuzzy AHP was used to analyze the structure of the supplier selection problem and to determine the weighting coefficients of the criteria while the fuzzy TOPSIS method was used to rank the suppliers. In the papers (Shaw et al., 2012; Shaw et al., 2013), the authors proposed a method based on fuzzy AHP and fuzzy multi-objective programming to select suppliers in the supply chain taking into account carbon emissions.

In addition to the AHP-QFD, a combination of ANP-QFD methods is often used in the literature for supplier selection. In the paper (Wu et al., 2013), they applied ANP in combination with fuzzy Delphi-TOPSIS methods to select the optimal supplier. The fuzzy Delphi method was used to select the evaluation criteria. Given the correlation of the selected criteria with each other, the ANP method was used to determine their weights. Finally, the TOPSIS method was used to rank alternatives. Galankashi et al. (2015) applied the nominal group technique (NGT) used to determine the most critical KPIs. After that, a fuzzy ANP was applied to determine the weights of the criteria for selecting a green supplier. Palanisamy and Zubar (2013) applied a combination of fuzzy QFD and ANP in their paper to perform supplier (seller) ranking. Namely, the fuzzy QFD method was first used to reduce the number of potential suppliers and to convert linguistic statements into quantitative values, after which the ANP method was applied to rank the selected suppliers. Bottani et al. (2018) in their paper developed the ANP-QFD method for supplier selection taking into account the BOCR (Benefits, Opportunities, Costs and Risks) model. Taghizadeh and Ershadi (2013) applied the ANP-QFD methodology for supplier selection for strategic items, leverage items and average items. By applying the mentioned methodology, they came to the conclusion that quality is the most important selection criterion. 
Based on the review of relevant literature and scientific approaches used in solving this very important and current issue, the authors decided to apply AHP-QFD and ANP-QFD methodology, which is presented in the next section.

\section{AHP-QFD and ANP-QFD Methodology}

AHP-QFD and ANP-QFD methodology contains the following steps: identification of requirements (WHATs), determination of supplier attributes (HOWs), determination of WHATs weights using AHP method, the formation of relationship matrix, calculation of HOWs weights, evaluation of suppliers using AHP and supplier ranking. The described methodology is shown in Figure 1. The identification of requirements as well as the determination of supplier attributes was performed using a QFD matrix. House of Quality (HoQ) differs from the standard in this methodology, as here the company determines what it takes for the product/ service to have in order to meet certain requirements of the company and then identifies the supplier's attributes that have the greatest impact on the achievement of set goals. In order to perform the evaluation within the relationship matrix, it was necessary to determine the weights of requirements (WHATs), which was done in this paper using AHP/ANP methods (using Saaty's scale). After that, the formation of the relationship matrix and calculation of weights of the supplier attributes (HOWs) was done. Determined criterion weights were then used in the AHP and ANP models to perform supplier evaluation and ranking.

In the literature, the AHP method is mainly used for decision-making that depends on several factors, and when it is possible to differentiate the decision-making process into a hierarchical structure (Owida et al., 2010). This is especially applied when choosing a supplier or a provider. Also, due to its nature, AHP allows the breakdown of complex problems into smaller levels (thanks to the hierarchical structure of the model). As the supplier selection process is a complex process, the authors considered that the application of the AHP method is the most suitable and for that reason, it is applied in this paper.

The ANP method is a more advanced version of the AHP method that is based on the network structure and more precisely defines the relationships within complex models as well as the interdependence of the criteria themselves. This method, which contains a feedback structure, enables network definition of problems, differing from the AHP method because it does not represent a linear hierarchy but examines the influences between network elements (compared to the AHP method where the comparison is made according to hierarchically higher levels). The ANP-QFD methodology is identical to the previously described AHP-QFD, where the difference is only reflected in the model. The combination of ANP-QFD methods was used in this paper to compare the results obtained using these methods with the results obtained using AHP and QFD methods. Also, another reason for application is to determine whether there will be a difference in the results when the interrelationships of the elements at different hierarchical levels are taken into account (which is the main difference of the ANP method in relation to AHP). 


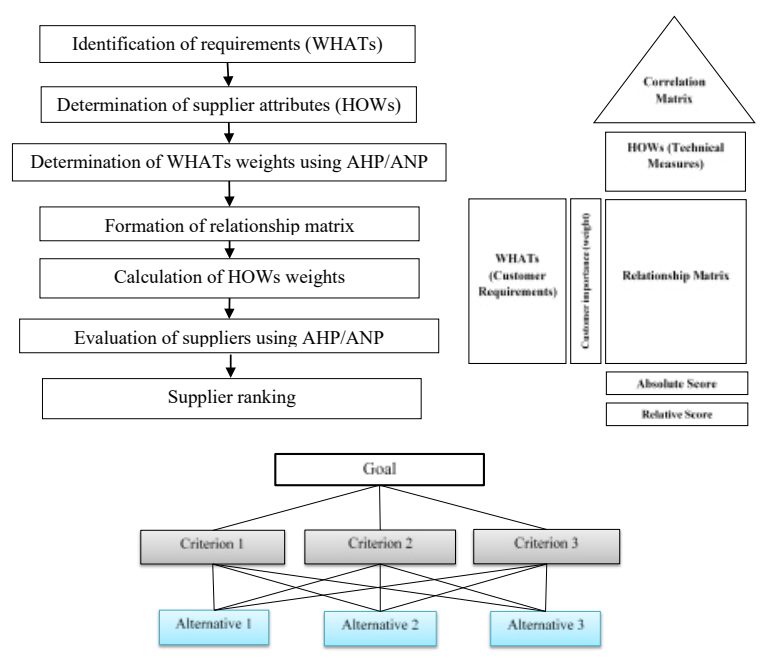

Fig. 1.

Methodology

\section{Results}

The developed methodology was tested and applied to a specific example of supplier selection by procurement logistics in a trading company operating in the Serbian market. The task was to select the most favorable of the three potential suppliers, having in mind the real requirements in the process of supplying the company and the key criteria for selecting suppliers. The research and selection of suppliers were based on the expert assessment of 10 managers with many years of experience in product procurement. In this paper, an affordable product, an adequate quality of the product, and timely delivery were considered as company requirements (WHATs in $\mathrm{HoQ}$ ), while price, product quality, on-time delivery, location, communication, reliability, flexibility, and reputation were observed as attributes of suppliers (HOWs). In the next part of the paper, the results obtained through the basic phases and steps of the research are presented, according to the described methodology.

\subsection{Results of AHP-QFD Methodology Application}

As already mentioned, an affordable product, adequate quality of the product and timely delivery were observed as company requirements (WHATs). In order to determine the weights of these requirements, the Saaty scale was used, which is used when applying the AHP method. Based on conversations with experts in the field of procurement, it was determined that an affordable product is the most important requirement. For this reason, it was estimated that this requirement is moderately dominant in relation to an adequate quality of the product (and for that reason, a value of 3 was assigned), Table 1 . In relation to timely delivery, this 
requirement is very strongly dominant (and for that reason, a value of 7 has been assigned). As the second requirement in terms of significance, adequate quality of product stood out, which when compared to timely delivery has a strong to very strong dominance, and for that reason, a value of 6 was assigned.

Table 1

Requirements Weights

\begin{tabular}{|c|c|c|c|c|c|}
\hline Requirement & $\begin{array}{c}\text { Affordable } \\
\text { Product }\end{array}$ & $\begin{array}{c}\text { Adequate } \\
\text { Quality of the } \\
\text { Product }\end{array}$ & $\begin{array}{l}\text { Timely } \\
\text { Delivery }\end{array}$ & & \\
\hline Affordable Product & 1 & 3 & 7 & & \\
\hline $\begin{array}{l}\text { Adequate Quality } \\
\text { of the Product }\end{array}$ & 0.33 & 1 & 6 & & \\
\hline Timely Delivery & 0.14 & 0.17 & 1 & & \\
\hline Sum & 1.47 & 4.17 & 14 & & \\
\hline & \multicolumn{3}{|c|}{ Normalized Matrix } & Sum & $\begin{array}{l}\text { Priority } \\
\text { Vector }\end{array}$ \\
\hline Affordable Product & 0.68 & 0.72 & 0.50 & 1.90 & 0.63 \\
\hline $\begin{array}{c}\text { Adequate Quality } \\
\text { of the Product }\end{array}$ & 0.22 & 0.24 & 0.43 & 0.89 & 0.30 \\
\hline Timely Delivery & 0.10 & 0.04 & 0.07 & 0.21 & 0.07 \\
\hline Sum & 1.00 & 1.00 & 1.00 & 3.00 & \\
\hline
\end{tabular}

After determining the weights of the requirements, which will then be used in the QFD matrix, the next step was the formation of the matrix within HoQ, Table 2. Given that the price of the product, as well as the quality, directly affect whether the product will be affordable, a strong relationship was estimated (9). On-time delivery and reputation can also have an impact on the affordability of a product, but this impact is not as pronounced and for this reason, the medium strong relationship was estimated (3). The location has a weaker impact in the following way, the closer the supplier's location is to the distribution center (DC) of the trader, the lower the price will be (since the transport distance is shorter), and for that reason, a weak relationship was estimated (1). On the other hand, the price and quality of the product directly affect the adequacy of the quality of the product being procured, and for that reason, a strong relationship has been estimated (9). Adequate quality of the product is also influenced by communication (better communication results in a better product), reliability (if the supplier is reliable in the past, it is more likely that it will remain so) and flexibility (primarily 
reflected in the ability to adapt to customer requirements). These are the reasons why a medium strong relationship was estimated (3). In addition, reputation can also have an impact on the adequate quality of the product (stronger brands usually have better quality products, although not necessarily) which is why a weak relationship was estimated (1). Finally, when timely delivery is observed, it can be concluded that this request is most influenced by on-time delivery, location, communication (refers to determining time window for receipt and unloading) and flexibility, and for these reasons, a strong relationship was estimated (9). In addition, this requirement is also influenced by quality and reliability, where the medium strong relationship was estimated (3).

Table 2

QFD Matrix

\begin{tabular}{|c|c|c|c|c|c|c|c|c|c|c|}
\hline \multirow{2}{*}{ WHATs } & \multirow{2}{*}{$\begin{array}{l}\text { Weight } \\
\text { by AHP }\end{array}$} & \multicolumn{8}{|c|}{ HOWs } & \multirow[b]{2}{*}{ Total Weight } \\
\hline & & Price & P. quality & $\begin{array}{l}\text { On-time } \\
\text { Delivery }\end{array}$ & Location & $\begin{array}{l}\text { Commu- } \\
\text { nication }\end{array}$ & $\begin{array}{l}\text { Reliabil- } \\
\text { ity }\end{array}$ & $\begin{array}{c}\text { Flexibil- } \\
\text { ity }\end{array}$ & $\begin{array}{c}\text { Reputa- } \\
\text { tion }\end{array}$ & \\
\hline $\begin{array}{l}\text { Affordable } \\
\text { Product }\end{array}$ & 0.63 & & 9 & 3 & 1 & & & & & 15.75 \\
\hline $\begin{array}{l}\text { Adequate } \\
\text { Quality } \\
\text { of the } \\
\text { Product }\end{array}$ & 0.30 & 9 & 9 & & & 3 & 3 & 3 & 0.30 & 8.4 \\
\hline $\begin{array}{l}\text { Timely } \\
\text { Delivery }\end{array}$ & 0.07 & & & 9 & 9 & 9 & 3 & 9 & & 2.94 \\
\hline \multicolumn{2}{|c|}{ Total Weight } & 8.37 & 8.58 & 2.52 & 1.26 & 1.53 & 1.11 & 1.53 & 2.19 & 27.09 \\
\hline \multicolumn{2}{|c|}{ Relative Weight } & 0.31 & 0.32 & 0.09 & 0.05 & 0.06 & 0.04 & 0.06 & 0.08 & \\
\hline
\end{tabular}

Based on the presented Table 2, it can be concluded that the three most important attributes of suppliers were product quality, price and on-time delivery. After determining the weights of the attributes using the QFD method, the analysis of suppliers was carried out which were then observed as alternatives in AHP and ANP methods. Based on the data of one trading company, 3 suppliers were evaluated according to 8 observed criteria. The selection of criteria was made on the basis of a literature review and on the basis of interviews with experts in the field of procurement logistics. Of the potential 12 criteria presented to the experts, based on their evaluation and literature review (number of papers in which these criteria were used), 8 key ones were defined which were then considered and used in the supplier evaluation process: price, product quality, on-time delivery, location, communication, reliability, flexibility, and reputation (Table 3). 
Table 3

Supplier Selection Criteria

\begin{tabular}{|c|c|c|}
\hline Criterion & Description & Reference \\
\hline Price & $\begin{array}{l}\text { Unit price, payment terms and discounts that can be } \\
\text { granted (when it comes to a larger quantity) where } \\
\text { considered under this criterion }\end{array}$ & $\begin{array}{l}\text { Watt et al. (2010); Bansal et al. (2013); } \\
\text { Akman and Baynal (2014); Jothimani } \\
\text { and Sarmah (2014); Hwang et al. (2016) }\end{array}$ \\
\hline Product Quality & $\begin{array}{l}\text { Quality level implies the ability of the supplier to } \\
\text { meet the required level of quality related to the } \\
\text { quality of products, production, packaging, etc. }\end{array}$ & $\begin{array}{l}\text { Jharkharia and Shankar (2007); Hsu } \\
\text { and } \mathrm{Hu}(2009) \text {; Kumar et al. (2012); } \\
\text { Jothimani and Sarmah (2014); Hwang et } \\
\text { al. (2016); Suraraksa and Shin (2019) }\end{array}$ \\
\hline On-time Delivery & $\begin{array}{l}\text { On-time delivery represents delivery that has been } \\
\text { made by the agreed time and in full (right goods, at } \\
\text { the right time at the right place) }\end{array}$ & $\begin{array}{l}\text { Ustun and Demirtas (2008); Hruška et. } \\
\text { al. (2014); Ozbek (2015); Hwang et al. } \\
\text { (2016) }\end{array}$ \\
\hline Location & $\begin{array}{l}\text { The distance of the supplier from the DC of the } \\
\text { retailer as well as the geographical coverage of Serbia } \\
\text { in terms of delivery possibilities were observed } \\
\text { within the location criteria }\end{array}$ & $\begin{array}{l}\text { Sarkar and Mohapatra (2006); Daim et } \\
\text { al. (2012); Kumar and Singh (2012) }\end{array}$ \\
\hline Communication & $\begin{array}{c}\text { Real-time information sharing and quality } \\
\text { communication can lead to savings in both time and } \\
\text { cost }\end{array}$ & $\begin{array}{c}\text { Sarkar and Mohapatra (2006); Uygun } \\
\text { (2013); Ozbek (2015); Suraraksa and } \\
\text { Shin (2019) }\end{array}$ \\
\hline Reliability & $\begin{array}{l}\text { Supplier reliability is primarily reflected in financial } \\
\text { stability, business history in previous years and } \\
\text { revenue generated in the previous year }\end{array}$ & $\begin{array}{l}\text { Jamil et al. (2013); Hruška et. al. (2014); } \\
\text { Suraraksa and Shin (2019) }\end{array}$ \\
\hline Flexibility & $\begin{array}{l}\text { The ability of the supplier to adapt to changes in } \\
\text { demand as well as the ability to adapt to sudden } \\
\text { changes in terms of delivery time }\end{array}$ & $\begin{array}{l}\text { Jamil et al. (2013); Uygun (2013); } \\
\text { Suraraksa and Shin (2019) }\end{array}$ \\
\hline Reputation & $\begin{array}{l}\text { The reputation of the brand and reputation of the } \\
\text { supplier on the market (observed in relation to the } \\
\text { realized sales in the last year) }\end{array}$ & $\begin{array}{l}\text { Watt et al. (2010); Kilic (2013); Akman } \\
\text { and Baynal (2014); Ozbek (2015) }\end{array}$ \\
\hline
\end{tabular}

The evaluation of suppliers was performed using a scale of 1-3, where the value of 1 represents the worst result according to criteria while the value of 3 represents the best result, Table 4 .

\section{Table 4}

Evaluation of Suppliers according to Criteria

\begin{tabular}{|c|c|c|c|}
\hline Criterion & Supplier 1 (V1) & Supplier 2 (V2) & Supplier 3 (V3) \\
\hline Price (C1) & 1 & 2 & 3 \\
\hline Product Quality (C2) & 2 & 1 & 3 \\
\hline On-time Delivery (C3) & 1 & 3 & 2 \\
\hline Location (C4) & 2 & 1 & 3 \\
\hline Communication (C5) & 3 & 2 & 1 \\
\hline Reliability (C6) & 3 & 2 & 1 \\
\hline Flexibility (C7) & 2 & 3 & 1 \\
\hline Reputation (C8) & 3 & 2 & 1 \\
\hline
\end{tabular}

The evaluation of suppliers according to criteria was done based on the following. In terms of price, supplier 1 is the worst since it is not able to provide as many discounts as the other two suppliers and is therefore rated the worst (1). Wh en looking at product 
quality then it can be concluded that the supplier in terms of quality is between the other two suppliers and for this reason is rated 2 according to this criterion. Service level for the previous 8 months was observed when estimating on-time delivery and as it was $83.95 \%$ in the case of this supplier compared to other suppliers is the worst result and therefore rated the worst (1). When estimating the location, the distance between the DC of the retailer and the supplier's location was observed, which in the case of the first supplier is $95 \mathrm{~km}$. In terms of communication, reliability and reputation, this supplier is better compared to other suppliers, which is why it is rated with 3 . When it comes to flexibility, this supplier is rated with 2 since it is better than supplier 3 and worse than supplier 2 (Table 4).

In terms of price, the second supplier is between the other two suppliers. When the level of quality is observed, then this supplier is the worst and for that reason, it was evaluated with 1 . The service level of this supplier was $101.26 \%$ which is also the best result according to this criterion. In terms of location, this supplier is the furthest from the
DC of the retailer $(182 \mathrm{~km})$ and is therefore rated the worst (1). According to the criteria of communication, reliability and reputation, this supplier is between the other two and is therefore rated with 2 . From the aspect of flexibility, this supplier is best rated as it is the most flexible in terms of adapting to customer requirements (Table 4).

In terms of price, the third supplier is the best as it can provide significant discounts on a larger quantity of requested products. The same situation is in terms of product quality, where this supplier can deliver the highest level of quality. The service level of this supplier was $87.49 \%$ which is why it is rated with 2 . In terms of location, this supplier is the closest to the DC $(32 \mathrm{~km})$, which is why it is rated with 3 according to this criterion. In terms of communication, reliability, flexibility and reputation, this supplier is the worst compared to the other two suppliers (Table 4).

The data in Table 4 were then used in the AHP model to evaluate each supplier. The layout of the AHP model used in this paper is shown in Figure 2.

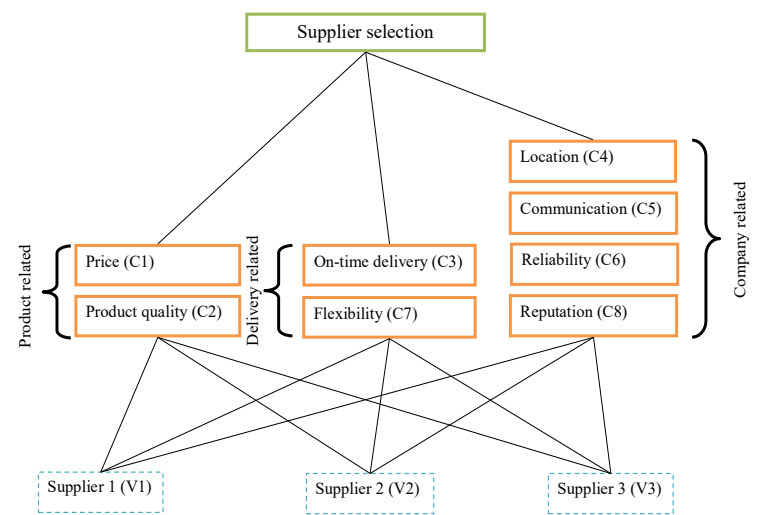

Fig. 2.

AHP Model 
SuperDecisions software was used to calculate the results using the AHP and ANP methods. After entering the input data into this software, an unweighted supermatrix shown in Table 5 was obtained.

\section{Table 5}

Unweighted AHP Supermatrix

\begin{tabular}{|c|c|c|c|c|c|c|c|c|c|c|c|c|c|}
\hline & & \multirow{2}{*}{$\begin{array}{c}\text { Goal } \\
\text { Goal }\end{array}$} & \multicolumn{8}{|c|}{ Criteria } & \multicolumn{3}{|c|}{ Alternatives } \\
\hline & & & $\mathrm{C} 1$ & $\mathrm{C} 2$ & $\mathrm{C} 3$ & $\mathrm{C} 4$ & $\mathrm{C5}$ & C6 & $\mathrm{C} 7$ & $\mathrm{C} 8$ & V1 & $\mathrm{V} 2$ & V3 \\
\hline Goal & 1GoalNode & 0 & 0 & 0 & 0 & 0 & 0 & 0 & 0 & 0 & 0 & 0 & 0 \\
\hline \multirow{8}{*}{ Criteria } & Price & 0.125 & 0 & 0 & 0 & 0 & 0 & 0 & 0 & 0 & 0 & 0 & 0 \\
\hline & Product Quality & 0.125 & 0 & 0 & 0 & 0 & 0 & 0 & 0 & 0 & 0 & 0 & 0 \\
\hline & On-time Delivery & 0.125 & 0 & 0 & 0 & 0 & 0 & 0 & 0 & 0 & 0 & 0 & 0 \\
\hline & Location & 0.125 & 0 & 0 & 0 & 0 & 0 & 0 & 0 & 0 & 0 & 0 & 0 \\
\hline & Communication & 0.125 & 0 & 0 & 0 & 0 & 0 & 0 & 0 & 0 & 0 & 0 & 0 \\
\hline & Reliability & 0.125 & 0 & 0 & 0 & 0 & 0 & 0 & 0 & 0 & 0 & 0 & 0 \\
\hline & Flexibility & 0.125 & 0 & 0 & 0 & 0 & 0 & 0 & 0 & 0 & 0 & 0 & 0 \\
\hline & Reputation & 0.125 & 0 & 0 & 0 & 0 & 0 & 0 & 0 & 0 & 0 & 0 & 0 \\
\hline \multirow{3}{*}{ Alternatives } & Supplier1 & 0 & 0.33 & 0.33 & 0.33 & 0.33 & 0.33 & 0.33 & 0.33 & 0.33 & 0 & 0 & 0 \\
\hline & \begin{tabular}{|l|} 
Supplier2 \\
\end{tabular} & 0 & 0.33 & 0.33 & 0.33 & 0.33 & 0.33 & 0.33 & 0.33 & 0.33 & 0 & 0 & 0 \\
\hline & Supplier3 & 0 & 0.33 & 0.33 & 0.33 & 0.33 & 0.33 & 0.33 & 0.33 & 0.33 & 0 & 0 & 0 \\
\hline
\end{tabular}

Then the evaluation of attributes in the inconsistency index was fulfilled relation to the goal and alternatives in relation to attributes was performed. During the evaluation, the condition of the AHP method which refers to considering that the value of $\mathrm{CR}$ was 0.09739 which is less than $10 \%$. After evaluation, the weighted supermatrix shown in Table 6 was obtained.

\section{Table 6}

Weighted AHP Supermatrix

\begin{tabular}{|c|c|c|c|c|c|c|c|c|c|c|c|c|c|}
\hline & & \multirow{2}{*}{$\begin{array}{c}\text { Goal } \\
\text { Goal }\end{array}$} & \multicolumn{8}{|c|}{ Criteria } & \multicolumn{3}{|c|}{ Alternatives } \\
\hline & & & $\mathrm{C} 1$ & $\mathrm{C} 2$ & C3 & $\mathrm{C} 4$ & $\mathrm{C} 5$ & C6 & $\mathrm{C} 7$ & $\mathrm{C} 8$ & $\mathrm{~V} 1$ & $\mathrm{~V} 2$ & V3 \\
\hline Goal & GoalNode & 0 & 0 & 0 & 0 & 0 & 0 & 0 & 0 & 0 & 0 & 0 & 0 \\
\hline \multirow{8}{*}{ Criteria } & $\mathrm{C} 1$ & 0.334 & 0 & 0 & 0 & 0 & 0 & 0 & 0 & 0 & 0 & 0 & 0 \\
\hline & $\mathrm{C} 2$ & 0.287 & 0 & 0 & 0 & 0 & 0 & 0 & 0 & 0 & 0 & 0 & 0 \\
\hline & C3 & 0.159 & 0 & 0 & 0 & 0 & 0 & 0 & 0 & 0 & 0 & 0 & 0 \\
\hline & $\mathrm{C} 4$ & 0.024 & 0 & 0 & 0 & 0 & 0 & 0 & 0 & 0 & 0 & 0 & 0 \\
\hline & C5 & 0.032 & 0 & 0 & 0 & 0 & 0 & 0 & 0 & 0 & 0 & 0 & 0 \\
\hline & C6 & 0.081 & 0 & 0 & 0 & 0 & 0 & 0 & 0 & 0 & 0 & 0 & 0 \\
\hline & \begin{tabular}{|l|}
$\mathrm{C} 7$ \\
\end{tabular} & 0.050 & 0 & 0 & 0 & 0 & 0 & 0 & 0 & 0 & 0 & 0 & 0 \\
\hline & $\mathrm{C} 8$ & 0.033 & 0 & 0 & 0 & 0 & 0 & 0 & 0 & 0 & 0 & 0 & 0 \\
\hline \multirow{3}{*}{ Alternatives } & V1 & 0 & 0.17 & 0.33 & 0.17 & 0.33 & 0.50 & 0.50 & 0.33 & 0.50 & 0 & 0 & 0 \\
\hline & $\mathrm{V} 2$ & 0 & 0.33 & 0.16 & 0.50 & 0.17 & 0.33 & 0.33 & \begin{tabular}{|l|}
0.50 \\
\end{tabular} & 0.33 & 0 & 0 & 0 \\
\hline & V3 & 0 & 0.50 & 0.50 & 0.33 & 0.50 & 0.17 & 0.17 & 0.17 & 0.17 & 0 & 0 & 0 \\
\hline
\end{tabular}


In order to obtain the final supplier rank, based on Table 6, the values of the alternatives by attributes were extracted and then multiplied by the values (relative weights) of the attributes obtained using the QFD method, which is shown in equation (1) below.

$\left(\begin{array}{llllllll}0,167 & 0,333 & 0,167 & 0,333 & 0,500 & 0,500 & 0,333 & 0,500 \\ 0,333 & 0,167 & 0,500 & 0,167 & 0,333 & 0,333 & 0,500 & 0,333 \\ 0,500 & 0,500 & 0,333 & 0,500 & 0,167 & 0,167 & 0,167 & 0,167\end{array}\right) \times\left(\begin{array}{l}0,31 \\ 0,32 \\ 0,09 \\ 0,05 \\ 0,06 \\ 0,04 \\ 0,06 \\ 0,08\end{array}\right)=\left(\begin{array}{l}0,29999 \\ 0,29996 \\ 0,41005\end{array}\right)$

Based on these results, it can be concluded that according to the applied AHP-QFD methodology, the final supplier rank is as follows: S3>S1>S2. So according to this methodology, the supplier S3 achieved the best results and it should be chosen.

\subsection{Results of ANP-QFD Methodology Application}

ANP-QFD methodology is identical to the AHP-QFD methodology, so the input data used in the AHP method is now used in the ANP method. The only difference between these methodologies is reflected in the model since the ANP model considers the interrelationship of criteria and alternatives.

In addition to the evaluation of the alternatives in relation to the attributes (with the AHP method), the ANP method also evaluated the attributes in relation to the alternatives. After the evaluation and application of the ANP method, a weighted supermatrix was obtained. On that occasion, the condition regarding the coefficient of inconsistency was met since it did not exceed 0.1 and was $0.09738 ; 0.09963$ and 0.09769 when attributes were compared to alternatives. The values of the weighted supermatrix are shown in Table 7.

Table 7

Weighted ANP Supermatrix

\begin{tabular}{|c|c|c|c|c|c|c|c|c|c|c|c|c|}
\hline & & \multicolumn{8}{|c|}{ Criteria } & \multicolumn{3}{|c|}{ Alternatives } \\
\hline & & $\mathrm{C} 1$ & $\mathrm{C} 2$ & $\mathrm{C} 3$ & $\mathrm{C} 4$ & $\mathrm{C} 5$ & C6 & $\mathrm{C} 7$ & $\mathrm{C} 8$ & V1 & $\mathrm{V} 2$ & V3 \\
\hline \multirow{8}{*}{ Criteria } & Price & 0 & 0 & 0 & 0 & 0 & 0 & 0 & 0 & 0.40 & 0.37 & 0.33 \\
\hline & Product quality & 0 & 0 & 0 & 0 & 0 & 0 & 0 & 0 & 0.25 & 0.27 & 0.29 \\
\hline & $\begin{array}{l}\text { On-time } \\
\text { Delivery }\end{array}$ & 0 & 0 & 0 & 0 & 0 & 0 & 0 & 0 & 0.15 & 0.15 & 0.16 \\
\hline & Location & 0 & 0 & 0 & 0 & 0 & 0 & 0 & 0 & 0.02 & 0.02 & 0.03 \\
\hline & Communication & 0 & 0 & 0 & 0 & 0 & 0 & 0 & 0 & 0.03 & 0.03 & 0.03 \\
\hline & Reliability & 0 & 0 & 0 & 0 & 0 & 0 & 0 & 0 & 0.07 & 0.07 & 0.08 \\
\hline & Flexibility & 0 & 0 & 0 & 0 & 0 & 0 & 0 & 0 & 0.05 & 0.06 & 0.06 \\
\hline & Reputation & 0 & 0 & 0 & 0 & 0 & 0 & 0 & 0 & 0.03 & 0.03 & 0.02 \\
\hline \multirow{3}{*}{ Alternatives } & Supplier1 & 0.17 & 0.33 & 0.17 & 0.33 & 0.50 & 0.50 & 0.33 & 0.50 & 0 & 0 & 0 \\
\hline & Supplier2 & 0.33 & 0.17 & 0.50 & 0.17 & 0.33 & 0.33 & 0.50 & 0.33 & 0 & 0 & 0 \\
\hline & Supplier3 & 0.50 & 0.50 & 0.33 & 0.50 & 0.17 & 0.17 & 0.17 & 0.17 & 0 & 0 & 0 \\
\hline
\end{tabular}


In order to obtain the final ranking of suppliers, as in the case of applying the AHPQFD methodology, the values of alternatives in accordance to attributes were extracted from Table 7, which were then multiplied by the values (relative weight) of attributes obtained using the QFD method, as shown in equation (2) below.

$\left(\begin{array}{llllllll}0,40 & 0,25 & 0,15 & 0,02 & 0,03 & 0,07 & 0,05 & 0,03 \\ 0,37 & 0,27 & 0,15 & 0,02 & 0,03 & 0,07 & 0,06 & 0,03 \\ 0,33 & 0,29 & 0,16 & 0,03 & 0,03 & 0,08 & 0,06 & 0,02\end{array}\right) \times\left(\begin{array}{l}0,31 \\ 0,32 \\ 0,09 \\ 0,05 \\ 0,06 \\ 0,04 \\ 0,06 \\ 0,08\end{array}\right)=\left(\begin{array}{l}0,2285 \\ 0,2262 \\ 0,2212\end{array}\right)$

Based on these results, it can be concluded that according to the applied ANP-QFD methodology, the final rank of the suppliers is as follows: $\mathrm{S} 1>\mathrm{S} 2>\mathrm{S} 3$. So, according to this methodology, unlike the AHP-QFD methodology, supplier S1 achieved the best results and it should be chosen. Based on these results, it can be concluded that when considering the interrelationships between attributes and alternatives, there was a change in the final rank of the supplier.

\section{Conclusion}

The issue of supplier selection is one of the basic ones in procurement logistics. Also, this issue is recognized both in the literature and in practice. The reason for this lies in the fact that the process of selecting suppliers can have a significant impact on a number of other activities in one company. This primarily refers to achieving savings, increasing efficiency, increasing flexibility, meeting user requirements, etc. For this reason, companies are paying more and more attention to the supplier selection process. In order to differentiate between certain suppliers, companies observe the issue of supplier selection from the aspect of several criteria, given that this process is very complex. On that occasion, in order to facilitate the decision-makers, it is often suggested to implement some of the methods of MCDM.

The aim of this paper was to propose one such methodology which, in addition to the method of multi-criteria decision-making, also relies on the QFD method, as one of the quality methods. In addition to AHP-QFD, the ANP-QFD methodology was applied in this paper to determine whether there is a difference in the final supplier rank. Three suppliers were analyzed using 8 criteria: price, product quality, on-time delivery, location, communication, reliability, flexibility, and reputation. Using the AHPQFD methodology, it was obtained that supplier S3 proved to be the best, while the application of the ANP-QFD methodology showed that supplier S1 proved to be the best solution. Based on these results, it can be concluded that the supplier selection process is a significant and complex issue that needs to be considered from several aspects. The application of the described methodology in order to determine from which DC it is necessary to ship goods stands out as one of the directions of future research. In addition, the development and application of other 
methods in order to select suppliers whose results would be compared with the results of this research is also one of the directions of future research.

\section{Acknowledgements}

This paper was supported by the Ministry of Education, Science and Technological Development of the Republic of Serbia, through the project TR 36006.

\section{References}

Akman, G.; Baynal, K. 2014. Logistics service provider selection through an integrated fuzzy multi-criteria decision making approach, Journal of Industrial Engineering 4: 1-17.

Bansal, A.; Kumar, P.; Issar, S. 2013. 3PL selection: A multi-criteria decision making approach. In Proceedings of Industrial Engineering and Engineering Management International Conference, Bangkok, Thailand, 981-985.

Bevilacqua, M.; Ciarapica, F.; Giacchetta, G. 2006. A fuzzy-QFD approach to supplier selection, Journal of Purchasing and Supply Management 12: 14-27.

Bhattacharya, A.; Geraghty, J.; Young, P. 2010. Supplier selection paradigm: An integrated hierarchical QFD methodology under multiple-criteria environment, Applied Soft Computing 10(4): 1013-1027.

Bottani, E.; Centobelli, P.; Murino, T.; Shekarian, E. 2018. A QFD-ANP Method for Supplier Selection with Benefits, Opportunities, Costs and Risks Considerations, International Journal of Information Technology \& Decision Making 17(3): 911-939.

Dai, J.; Blackhurst, J. 2012. A four-phase AHP-QFD approach for supplier assessment: A sustainability perspective, International Journal of Production Research 50(19): 5474-5490.
Daim, T. U.; Udbye, A.; Balasubramanian, A. 2012. Use of analytic hierarchy process (AHP) for selection of 3PL providers, Journal of Manufacturing Technology Management 24(1): 28-51.

Galankashi, M.R.; Chegeni, A.; Soleimanynanadegany, A.; Memari, A.; Anjomshoae, A.; Helmi, S.A.; Dargi, A. 2015. Prioritizing green supplier selection criteria using fuzzy analytical network process, Procedia CIRP 26: 689-694.

Ho, W.; Dey, P.; Lockstrom, M. 2011. Strategic sourcing: A combined QFD and AHP approach in manufacturing, Supply Chain Management: an International Journal 16(6): 446-461.

Hruška, R.; Pruša, P.; Babić, D. 2014. The use of AHP method for selection of supplier, Transport 29(2): 195-203.

Hsu, C.W.; Hu, A.H. 2009 Applying hazardous substance management to supplier selection using analytic network process, Journal of Cleaner Production 17(2): 255-264.

Hwang, B. N.; Chen, T. T.; Lin, J. T. 2016. 3PL selection criteria in integrated circuit manufacturing industry in Taiwan, Supply Chain Management: an International Journal 21(1): 103-124.

Jamil, N.; Besar, R.; Sim, H. K. 2013. A Study of Multicriteria Decision Making for Supplier Selection in Automotive Industry, Journal of Industrial Engineering 1-22.

Jharkharia, S.; Shankar, R. 2007. Selection of logistics service provider: An analytic network process (ANP) approach, Omega 35(3): 274- 289.

Jothimani, D.; Sarmah, S. P. 2014. Supply chain performance measurement for third party logistics, Benchmarking: an International Journal 21(6): 944-963.

Kilic, H. S. 2013. An integrated approach for supplier selection in multi-item/multi-supplier environment, Applied Mathematical Modelling 37(14): 7752-7763. 
Kumar, P.; Singh, R.K. 2012. A fuzzy AHP and TOPSIS methodology to evaluate $3 \mathrm{PL}$ in a supply chain, Journal of Modelling in Management 7(3): 287 - 303.

Kumar, R.; Singh, H.; Dureja, J. S. 2012. An approach to analyze logistic outsourcing problem in mediumscale organization by CFPR and VIKOR, Journal of Manufacturing Technology Management 23(7): 885-898.

Owida, A.M.; El-Kilany, K.S.; El-Sayed, A.E. 2010. In Proceedings Flexible Automation and Intelligent Manufacturing FAIM, California, 1-8.

Ozbek, A. 2015. Supplier Selection with Fuzzy TOPSIS, Journal of Economics and Sustainable Development 6(18): 114-125.

Palanisamy, P.; Zubar, H.A. 2013. Hybrid MCDM approach for vendor ranking, Journal of Manufacturing Technology Management 24(6): 905-928.

Polat, G.; Eray, E.; Bingol, B.N. 2017. An integrated fuzzy MCGDM approach for supplier selection problem, Journal of Civil Engineering and Management 23(7): 926942 .

Rajesh, G.; Malliga, P. 2013. Supplier Selection Based on AHP QFD Methodology, Procedia Engineering 64: 1283-1292.

Sarkar, A.; Mohapatra, P.K.J. 2006. Evaluation of supplier capability and performance: A method for supply base reduction, Journal of Purchasing and Supply Management 12(3): 148-163.

Scott, J.; Ho, W.; Dey, P.; Talluri, S. 2015. A decision support system for supplier selection and order allocation in stochastic, multi-stakeholder and multi-criteria environments, International Journal of Production Economics 166: 226-237.
Shaw, K.; Shankar, R.; Yadav, S.S.; Thakur, L.S. 2012. Supplier selection using fuzzy AHP and fuzzy multiobjective linear programming for developing low carbon supply chain, Expert Systems with Applications 39: $8182-8192$.

Shaw, K.; Shankar, R.; Yadav, S.S.; Thakur, L.S. 2013. Global supplier selection considering sustainability and carbon footprint issue: AHP multi-objective fuzzy linear programming approach, International Journal of Operational Research 17(2): 215-247.

Suraraksa, J.; Shin, K.S. 2019. Comparative Analysis of Facotrs for Supplier Selection and Monitoring: The Case of the Automotive Industry in Thailand, Sustainability 11: 981-994.

Taghizadeh, H.; Ershadi, M. 2013. Supplier's Selection in Supply Chain with Combined QFD and ANP Approaches, Research Journal of Recent Sciences 2(6): 66-76.

Ustun, O.; Demirtas, E.A. 2008. Multi-period lot-sizing with supplier selection using achievement scalarizing functions, Computers \& Industrial Engineering 54(4): 918931.

Uygun, Ö.; Kaçamak, H.; Ayşim, G.; Şimşir, F. 2013. Supplier selection for automotive industry using multicriteria decision making techniques, TOJSAT: the Online Journal of Science and Technology 3(4): 126-137.

Watt, D.J.; Kayis, B.; Willey, K. 2010. The relative importance of tender evaluation and contractor selection criteria, International Journal of Project Management 28(1): 51-60.

Wu, C.M.; Hsieh, C.L.; Chang, K.L. 2013. A hybrid multiple criteria decision-making model for supplier selection, Mathematical Problems in Engineering 1-8. 